\title{
POTENCIALIDADES DO GPS EM LEVANTAMENTOS GEOFÍSICOS TERRESTRES
}

\author{
Marcelo Soares Teles dos Santos \\ Orientador: Dr. Nelsi Côgo de Sá (IAG-USP) \\ 140 p. - Dissertação (Mestrado) - Defesa 13.06.2005
}

\begin{abstract}
RESUMO. Os levantamentos geofísicos terrestres consistem nas medições de grandezas físicas na superfície da Terra com o objetivo de estudar a estrutura e as propriedades físicas com aplicações na exploração de recursos naturais. Tais levantamentos requerem posicionamentos geográfico e altimétrico dos locais das medições para processamento, representação e análise dos dados. 0 uso de GPS oferece vários benefícios em relação aos métodos tradicionais de posicionamento. Mas, para sua adequada utilização, devem ser adotados alguns critérios na aquisição e no processamento de dados, os quais são definidos em função das características de cada levantamento como precisão requerida, extensão da área e resolução espacial. A partir do posicionamento GPS de um perfil contendo 38 Referências de Nível, localizado no Estado de São Paulo, foram indicados procedimentos de uso de GPS em levantamentos geofísicos terrestres. Como referência, foi usado o posicionamento relativo estático, com sessões de 60 minutos e receptores de dupla frequiência. As coordenadas geodésicas foram determinadas por meio de diversas estratégias de processamento, variando o tipo de receptores utilizados (simples e dupla freqüência), o número de bases (1 e 3), o comprimento das bases (2 a $250 \mathrm{~km}$ ) e a duração da sessão (10 a 60 minutos). As altitudes ortométricas foram determinadas no modo relativo, usando-se as 5 estações da RGSP mais próximas pelo programa computacional desenvolvido. 0 modelo goidal foi ajustado ao sistema altimétrico por meio da modelagem da componente sistemática. Os resultados obtidos com essas estratégias forneceram os seguintes indicadores: a acurácia do posicionamento por GPS é proporcional à duração da sessão; usando receptores de frequiência simples ocorre grande variação dos resíduos com o comprimento da base, aumentando a deterioração dos resultados para bases maiores que $30 \mathrm{~km}$; com receptores de dupla frequêencia, a acurácia do posicionamento praticamente não se altera com 0 comprimento da base; 0 aumento do número de bases melhora 0 ajustamento e a acurácia das coordenadas; e a acurácia das altitudes ortométricas está na margem de erro das altitudes geométricas, apresentando comportamento semelhante em relação à duração da sessão e ao comprimento da base. Com base nos resultados obtidos, foram definidos os métodos de posicionamento GPS para levantamentos geofísicos locais e regionais, de acordo com suas características. Assim, para obter-se acurácia de $10 \mathrm{~cm}$ com bases maiores de que $30 \mathrm{~km}$, deve-se usar receptores de dupla freqüência e sessões de no mínimo 30 minutos. Com bases menores do que $30 \mathrm{~km}$, pode-se usar receptores de dupla ou simples frequeência e sessões de 30 minutos.
\end{abstract}

ABSTRACT. Terrestrial geophysical surveys consist in measurements of physical quantities in Earth' surface aiming to study its structure and physical properties with applications in natural resources exploration. Such surveys require geographical and altimetric positionings of measurements places for processing, representation and analysis of data. The GPS positioning offers several benefits compared to the traditional positioning methods. These benefits are the high precision, operational simplicity, quickness and low cost. However, for its adequate utilization, some criteria must be adopted in data collection and data processing, which are defined from characteristics of each survey, such as required precision, extension of the area, and spatial resolution. From the GPS positioning of a 38 bench marks profile located in São Paulo State, some procedures to GPS use in terrestrial geophysical survey were recommended. The static relative positioning by dual frequencies receivers, from sessions of 60 minutes, was used as reference. The geodetic coordinates were obtained by using several processing strategies, varying the receiver type (single and dual frequencies), the number of baselines ( 1 and 3 ), the length of baseline ( 2 to $250 \mathrm{~km}$ ) and the session time (10 to 60 minutes). The orthometric heights were obtained in a relative way, using 5 nearest stations RGSP by the developed computer program. The geoid model was adjusted to the altimetric system by modelling the systematic component. The results obtained from these strategies have provided the following indicators: the accuracy of GPS positioning is proportional to the session time; by using single frequency receivers, the residuals show large variation with baseline length, deterioring more the results for baseline grater than $30 \mathrm{~km}$; by using dual frequency receivers, the accuracy of GPS positioning does not change itself with the baseline length; increasing the number of baselines the adjustment and accuracy of geodetic coordinates obtained in GPS positioning are improved; and the accuracy of orthometric heights obtained has the same margin error of geometric heights, presenting identical behavior in relation to session duration and to baseline length. From obtained results, the GPS positioning methods were specified to local and regional geophysical surveys, according to its characteristics. Therefore, to obtain an accuracy of $10 \mathrm{~cm}$ from baselines greater than $30 \mathrm{~km}$, dual frequency receivers and sessions greater than 30 minutes must be used. For baselines lower than $30 \mathrm{~km}$, most be used dual or single frequency receivers and 30 minutes sessions. 